\title{
Time for a new vision of doctoring
}

\section{Doctors have been gentlemen, technicians, benefactors and scientists, but now must be leaders}

hundred or more years ago, a doctor was a gentleman with warm hands, a smart suit, a whiff of philosophy and limited therapeutic powers. He - they were almost all male then could hack off gangrenous limbs and set bones, although with pills "little less mischievous than the shots from revolvers", ${ }^{1}$ he probably killed more than he saved; but he was well paid for his trouble. As the American anaesthetist and political philosopher (what a combination) Ronald W Dworkin writes in an essay, Re-imagining the doctor, a debate arose a century ago about what distinguished doctors from other caregivers and how many were needed. ${ }^{1}$ The same debate arises today, as there are calls across the world for more doctors, while others are arguing that doctors can be largely replaced by a mix of nurses, community health workers, robots and computers. Dworkin argues that what we need is not more doctors but "an altogether new vision of doctoring". He's right.

Dworkin thinks that present-day doctors are a mix of four types of doctor who emerged in the 19th century the gentleman, the technician, the benefactor and the scientist.

The gentleman doctor, still present today, is "regularly bred" and of "steady character". He is an artist, not a scientist, and recognises that "the human condition is too complicated to be reduced to universal principles". Character is more important than scientific acumen, and he does not allow his "astuteness to degenerate into profundity".

Next came the doctor as technician, akin to "a fine watchmaker". He (again, I'll stick with "he" to reflect the reality of the time, while also simplifying my grammar) excelled at practical things and avoided useless scientific theories. Medical schools, he believed, should "help students provide day-to-day medical care rather than teaching obscure subjects that would be speedily forgotten after class ... an education steeped in the latest scientific research was a waste of time". I hear many present-day medical students applauding.

The doctor as benefactor is perhaps seen less often today, although those who work for Médecins Sans Frontières may be the best current examples of this role. For the doctor-benefactor, "science should be subordinate to the caring impulse". He is "faithful to a higher law of morality" and is not paid a salary or fees but an honorarium. To pursue medicine "for its pecuniary remuneration would be to degrade one of the most sublime vocations". American medical students who graduate with debts of $\$ 200000$, many of whom aspire to be dermatologists and combine a high income with many nights in bed, may disagree.

Abraham Flexner is the man who dominates contemporary thinking about doctors through his report of 1910. ${ }^{2}$ Flexner believed that doctors must become

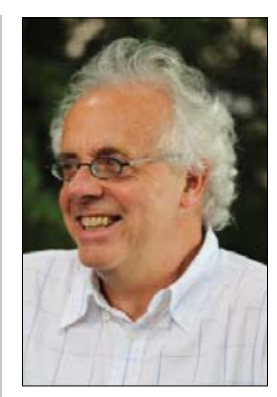

Richard SW Smith FMedSci, FRCPE, FRCGP

Chair

Patients Know Best, London, UK.

richardswsmith@ yahoo.co.uk

doi: 10.5694/mjal4.00765

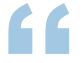

All four of these models are now collapsing. Hoi polloi - people like me, and even women have invaded the profession scientists. They must master the laws of medicine that "are no less exact and inevitable than the law of gravity or the movement of stars". Doctors must not fall into habit, but should test hypotheses to combat disease and assimilate new scholarship. Scientific organs, like the $M J A$, would help them in their sacred task.

All four of these models are now collapsing. Hoi polloi - people like me, and even women - have invaded the profession, undermining the gentleman role. Technology has replaced the technician, with the computed tomography scan compensating "for the bad neurologist" and "the pulse oximeter... for the bad anesthesiologist", in Dworkin's words. Soon robots will replace surgeons, as they have pilots, leaving the human roles open for actors who can portray the role of surgeons and pilots more convincingly than the real thing. Doctors as benefactors have largely disappeared, as they have become less religious and more greedy. Doctor-scientists, says Dworkin, have simply failed to deliver, with advances coming not from university scientists but from doctor-technicians working for pharmaceutical or medical device companies. Plus, doctor-scientists are seen as "cold and aloof", more interested in cells and organs than whole people.

So we have the paradox of being unsure what doctors are for, just as there are calls for more of them - another 30000 general practitioners in Britain, says the British Medical Association, and 214000 more doctors in the United States. ${ }^{3}$ More of the present chimera cannot be the answer, not least because it's unaffordable unless British, American and Australian doctors are willing to be paid like Cuban doctors.

For Dworkin, the future of doctors is to become leaders. A similar model, put to me by the dean of a German medical school, is that, instead of trying to solve people's problems through the natural sciences, doctors should become change agents, helping people change to live healthier lives, adapt to living with chronic and multiple conditions, and accept the inevitability of death. The patient with acute meningitis depends on the skill of the doctor, but how well people with multiple chronic conditions fare depends much more on them than on their doctors.

Doctors as leaders, writes Dworkin, "must emphasize their prudential and diplomatic skills in mediating between people, managing expectations, and inspiring hope". He believes that doctors are well positioned to be leaders because of "their extensive knowledge base". They also need "confidence and charisma - the virtues of a politician", a proposition that will not excite presentday doctors, who come top of the trust league, while politicians languish at the bottom. ${ }^{4}$

It's clear to me that the new vision of doctoring must mean doctors working more as leaders and less with individual patients. I think of an American AIDS doctor I met in Kenya. When he arrived, the care of AIDS patients took place entirely in the hospital and consisted essentially of managing their deaths. Together with 
many others, the doctor established a system involving six levels of health workers, with those at the lowest level going house to house, arranging testing for HIV. The system also incorporates electronic records and careful monitoring of all that is happening. This doctor now cares for more patients in Kenya than do all the AIDS doctors in his home state in the US. Most of the care he delivers is delivered through others. This can, I suggest, be achieved right across medicine and will mean not poorer but better care, as health care workers do what they do best and patients are encouraged to take charge of their own health. "Medicine, in this age of chronic disease", writes Dworkin, "consists of managing expectations, raising hopes, and commanding a welltrained team".

I do, however, see challenges ahead. I've been interested in leadership ever since I attended the Stanford Business School, and I know that doctors have problems with leadership. They are inclined to create unleadable organisations and then elect compromise candidates to lead them. I'm thinking of the British Medical Association and most organisations of British doctors. Medical associations the world over seem to be against change, rather than for proposing reforms, and, as John Green, once chief executive of the Royal Society of Medicine, said to me, "there is no kingdom too small for a doctor to be king of". ${ }^{5}$ Doctors are also poor at followership, a prerequisite for effective leadership.
Present-day doctors often feel most comfortable working as individuals. They are trained to minimise risk, when leadership is about taking risks. They are uneasy with power, uncomfortable with emotion, think it presumptuous to set a vision for an organisation, are not used to thinking about systems, and are driven by science and suffering to behave tactically rather than to think strategically.

So to achieve the vision of doctors as leaders, we will need to select different sorts of individuals from those we choose now and train them in different ways - an exciting challenge for the next 100 years.

Competing interests: I have received travel assistance to speak at the MJA Centenary Symposium.

Provenance: Commissioned; not externally peer reviewed.

1 Dworkin RW. Re-imagining the doctor. National Affairs 2014; (18). http:// www.nationalaffairs.com/publications/detail/re-imagining-the-doctor (accessed Jun 2014).

2 Flexner A. Medical education in the United States and Canada: a report to the Carnegie Foundation for the Advancement of Teaching. New York: Carnegie Foundation for the Advancement of Teaching, 1910.

3 Sargen M, Hooker RS, Cooper RA. Gaps in the supply of physicians, advance practice nurses, and physician assistants. J Am Coll Surg 2011; 212: 991-999.

4 Ipsos MORI. Trust in professions: poll. London: Ipsos MORI, 2013. http:// www.ipsos-mori.com/researchpublications/researcharchive/15/Trust-inProfessions.aspx (accessed Jun 2014).

5 Smith R. Medical professionalism: out with the old and in with the new. JR Soc Med 2006; 99: 48-50. 